Deborah A. Thomas

\section{EXCEPTIONAL violence}

Embodied Citizenship in Transnational Jamaica

Duke University Press

Durham and London 2011 
(C) 2011 Duke University Press

All rights reserved

Printed in the United States of America on acid-free paper @

Designed by Heather Hensley

Typeset in Arno Pro by Tseng Information Systems, Inc.

Library of Congress Cataloging-in-Publication Data appear on the last printed page of this book. 
for Vinny

AND ALL WHO LOVED HIM 
